\title{
NONLINEAR STRUCTURAL ANALYSIS OF THE ELLIPTICAL DOME OF THE CHURCH IN THE UNIVERSIDAD LABORAL, GIJON, SPAIN
}

\author{
JUAN JOSÉ DEL COZ-DIAZ ${ }^{1 *}$, ALFONSO LOZANO MARTINEZ-LUENGAS ${ }^{2}$, MAR \\ ALONSO-MARTINEZ ${ }^{2}$, PILAR GARCIA-CUETOS ${ }^{3}$ AND FELIPE PEDRO \\ ALVAREZ-RABANAL ${ }^{2}$ \\ ${ }^{1}$ GICONSIME Research Team - University of Oviedo \\ Viesques Departmental Building, 7 - Office 7.1.02. 33204 Gijon, Asturias (Spain) \\ e-mail: delcoz@uniovi.es, giconsime.grupos.uniovi.es \\ ${ }^{2}$ Department of Construction and Manufacturing, EPI Gijón, University of Oviedo \\ Viesques Departmental Building, 7 - Office 7.1.04. 33204 Gijon, Asturias (Spain) \\ ${ }^{3}$ Department of Art History and Musicology, Faculty of Philosophy \\ University of Oviedo \\ Teniente Alfonso Martínez s/n 33011 Oviedo, Asturias (Spain) \\ email: alozano@ uniovi.es, mar@ constru.uniovi.es, gcuetos@ uniovi.es, felipe@ constru.uniovi.es, \\ giconsime.grupos.uniovi.es
}

Keywords: Historical Structure, Masonry, Monitoring, Non-Destructive Inspection

\begin{abstract}
The Church of the Laboral University of Gijon has the world's largest elliptical masonry roof with 40.8 meters of mayor axis. This big structure is vertically supported with no columns using twenty pairs of masonry ribs crossing each other, and horizontally supported by means of two elliptical ring beams located at the top of the Church. In order to study this historical building, this paper presents the overall threedimensional structural numerical analysis of the Church, taking into account different material nonlinearities - including masonry and reinforced concrete - as well as geometrical nonlinearities, such as contact effects among the different structural components of the building. Furthermore, a coupled thermal-structural analysis was carried out considering the summer temperature distribution and the Spanish standard rule dead and live loads. The most relevant results, in terms of maximum displacement, stress and, cracking and crushing phenomena are presented. Finally, valuable information from the interaction among the structural elements of the Church are discussed and the most critical points of the building are located, giving place to the most important conclusions of the nonlinear numerical analysis of this interesting structure.
\end{abstract}

\section{INTRODUCTION}

The Universidad Laboral of Gijón was built between 1946 and 1956. With 270,000 m², it was the most important architectural work in the twentieth century and is still the largest building in Spain [1]. The church building (see Figure 1) is undoubtedly the most spectacular 
architectural ensemble of the Universidad Laboral in Gijón. With an overall inside surface of $807 \mathrm{~m}^{2}$, the church has the world's largest elliptical roof: with a major axis of $40.8 \mathrm{~m}$ and a minor axis of $25.2 \mathrm{~m}$. The church is twenty-five meters high from the floor to the springing line, and thirty-three meters high to the crown. The dome has an estimated weight of 2,300 tons. For its construction, 450,000 annealed bricks from the province of León (Spain) were used. The whole structure is self-supported with twenty pairs of interlaced masonry ribs. In the crown, there is an oculus to light the interior of the Church naturally. Currently however, there is no natural lighting due to a slight sag in the dome.

The structural analysis of masonry structures, and in particular of domes, has several difficulties: nonlinearities due to the material properties, with almost no tensile strength; the lack of experimental characterisation of the mechanical properties of masonry structural elements; and in this particular case, the complexity of the geometry [2].

To solve this complex structural problem, refined mechanical models, which accurately predict the behaviour of masonry material and elements, are proposed in the literature [3-6]. These models use different strategies to consider the highly nonlinear behaviour of the material both in tension where low tensile capacity and consequent cracking phenomena are taken into account, and in compression. Some of those models are also able to provide the structural response to large displacements. Unfortunately, current models are difficult to apply to a 3D analysis of complex structural systems. This is due to the great number of parameters involved in the definition, and the large number of degrees of freedom required for structural meshing, leading to unmanageable data. In this work, a nonlinear structural static analysis of the elliptical dome of the church is de cracking and crushing

Finally, valuable inf elements of the structure are structural analysis are dr
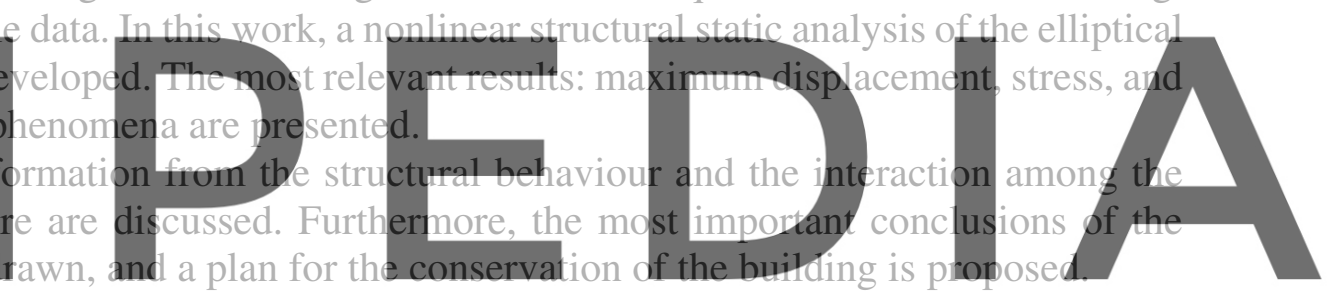


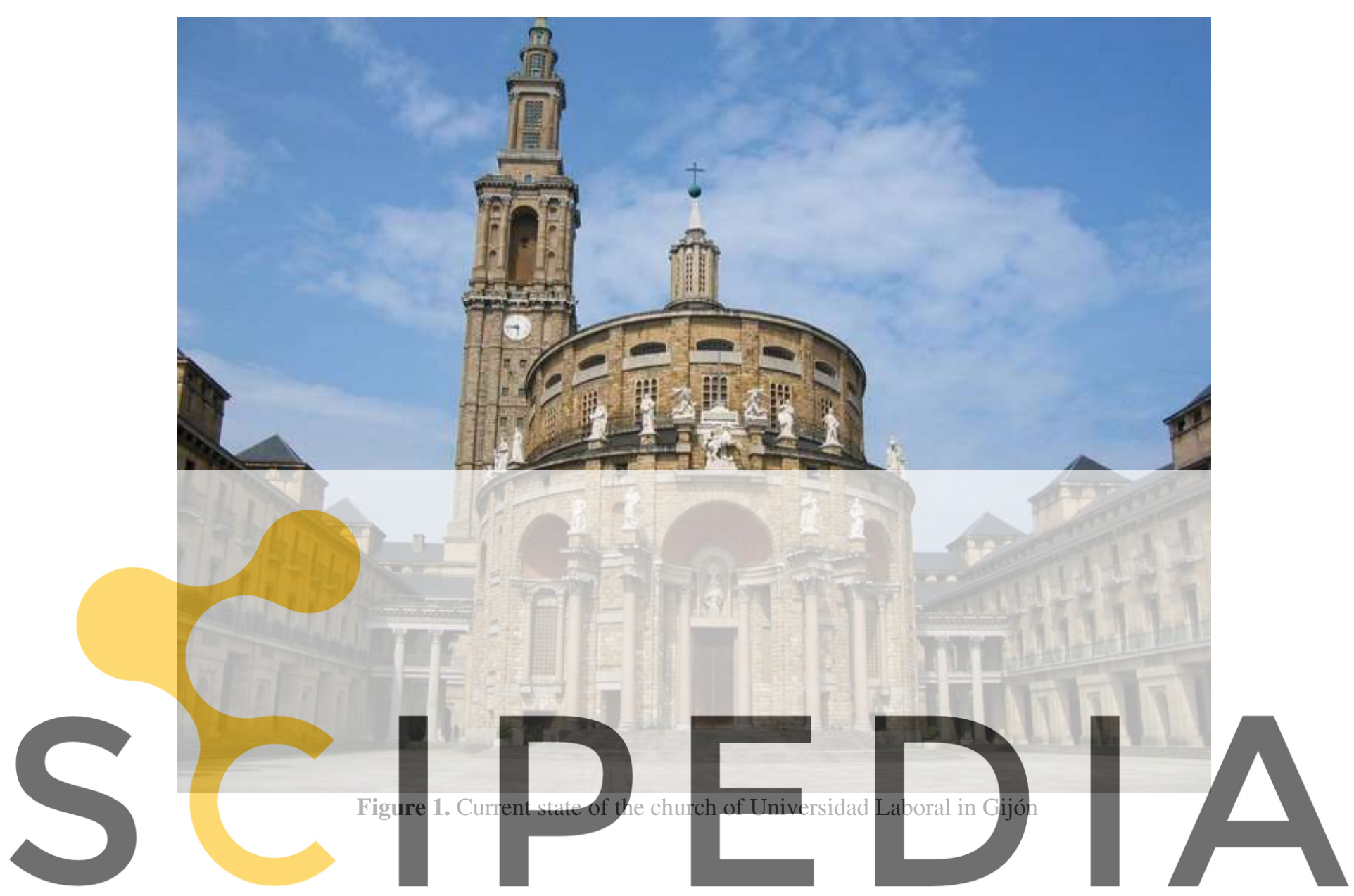

Register for free at https//www.scipedia.com to download the version without the watermark

\section{DESCRIPTION OF THE CHURCH IN THE UNIVERSIDAD LABORAL}

Traditional church buildings are often in the shape of a cross, and frequently have a tower or dome. However, the Church of the Laboral is completely different, since the roof has an elliptical shape [7] (see Fig.2).

The main parts of the system are described as follows:

- Masonry ribs: There are 20 interlaced pairs of brick ribs, stretching from the columns to the central skylight. They are rectangular in cross section, $0.9 \mathrm{~m}$ wide and from 1.8 to $2 \mathrm{~m}$ high, with variable lengths up to $16.8 \mathrm{~m}$. The main function of these elements is to transmit forces from the dome to the columns.

- $\quad$ Ring beams: There are two elliptical ring beams located at the top of the columns: upper and lower. Both of them are made of reinforced concrete. 


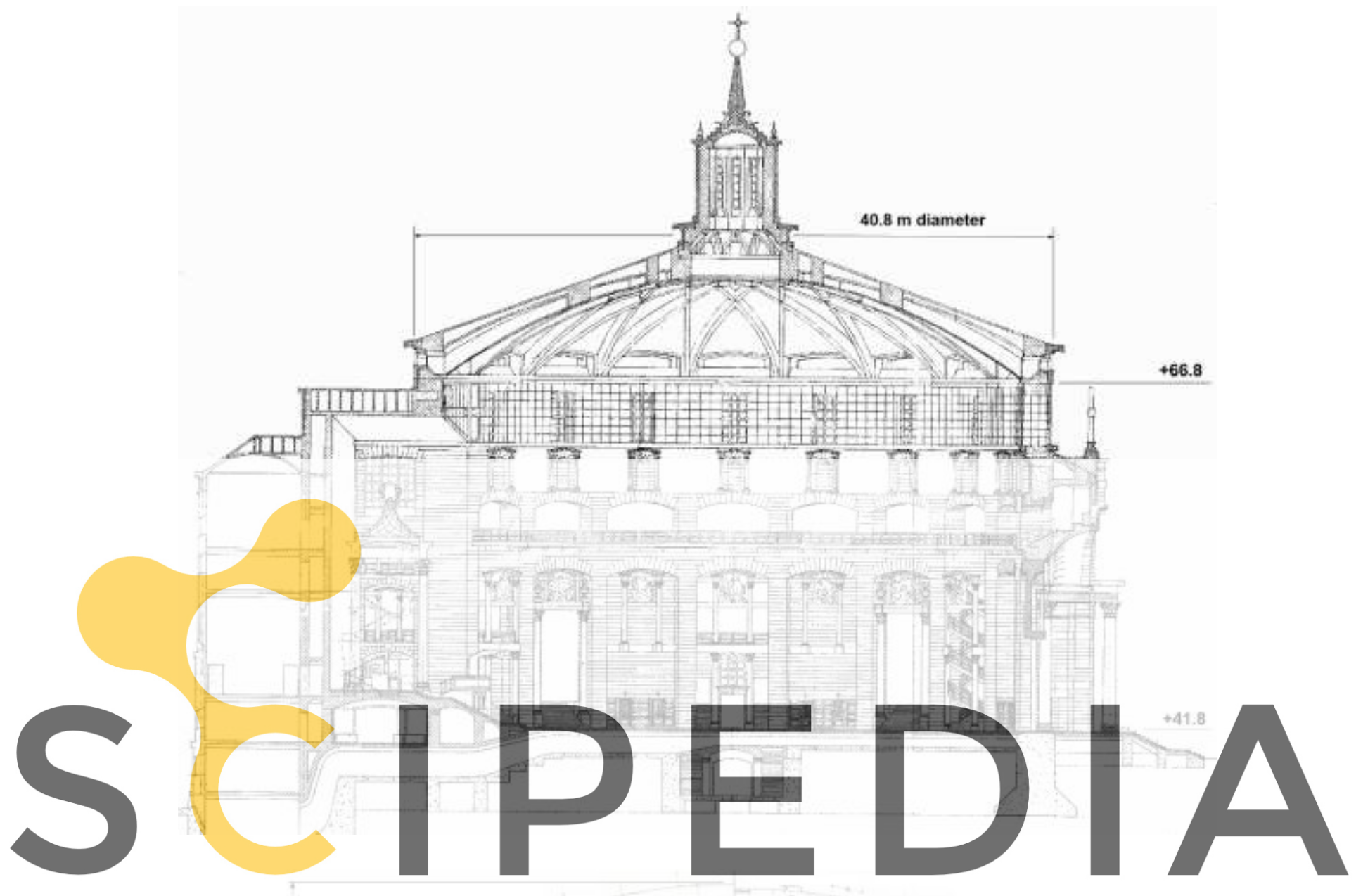

Register for free at https//www.scipedia.com to download the version without the watermark

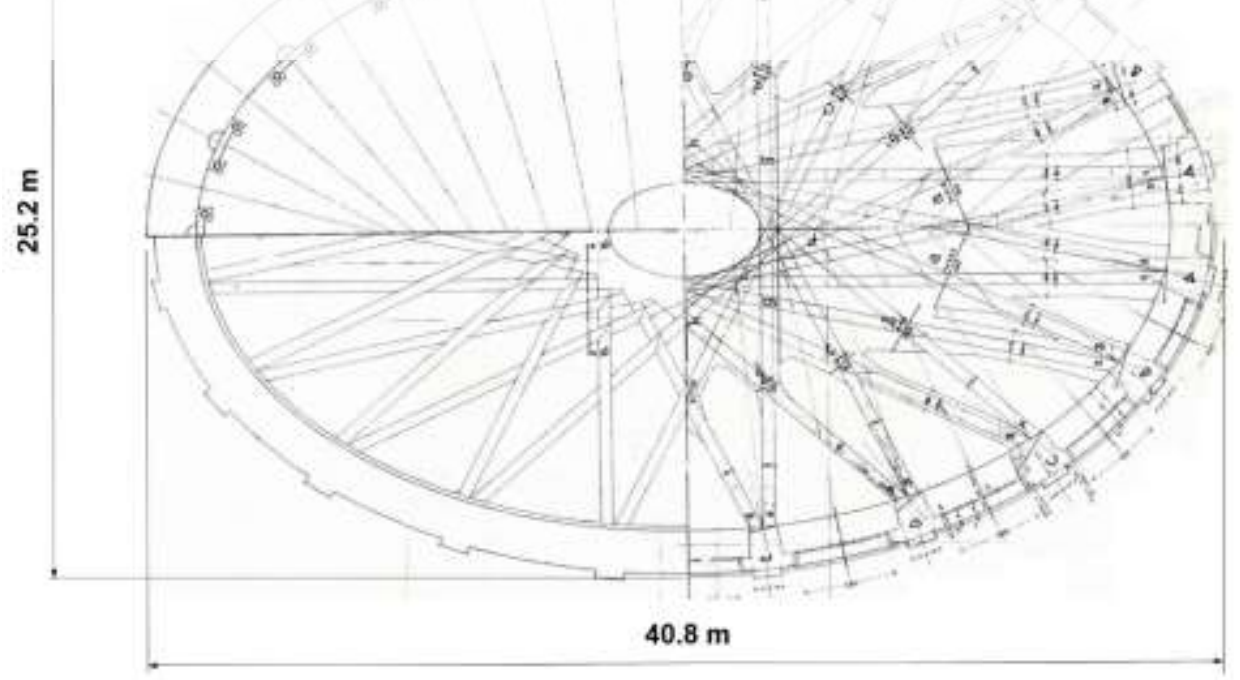

Figure 2. Church of the Laboral with main dimension: elevation view (upper) and plan of the dome (lower) 


\section{STRUCTURAL ANALYSIS}

Analysis of the structural response of masonry structures, and in particular of domes, is complex. The nonlinear material properties of masonry, with almost no tensile strength, must be considered in the numerical model. In addition, there is a lack experimental data of the mechanical properties of the masonry. Finally, this case is particularly complex due to geometry of the dome which is elliptical in shape and has double curvature on three axes [7].

Previous numerical models [2,5-6] are able to provide the structural response to large cyclic deformations, which occur under seismic actions. However, there are no 3D numerical models able to analyze complex geometries like the case studied in this work.

The numerical simulation carried out in this work uses the ANSYS Workbench 2019 R2 academic software. The numerical simulation developed gives great insight into the structural response of the dome, saving costs and time in relation to experimental tests [8-9].

\subsection{Geometrical model}

The 3D geometrical model of the dome was based on the project of the building (see Fig. 2). It was done using a parametric CAD software. The main elements considered are the following:

- Masonry ribs: elliptical arches of the dome made of masonry and concrete.

- Ring beams: there are two ring beams made of reinforced concrete to support the

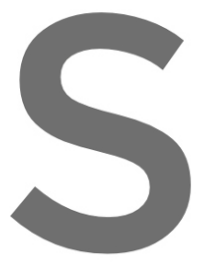
masonry ribs, the upper ring and the lower ring.

- Roof: the conical auxiliary structurc over the ribs, central skylight.

Columns: there are twenty main building supports made of
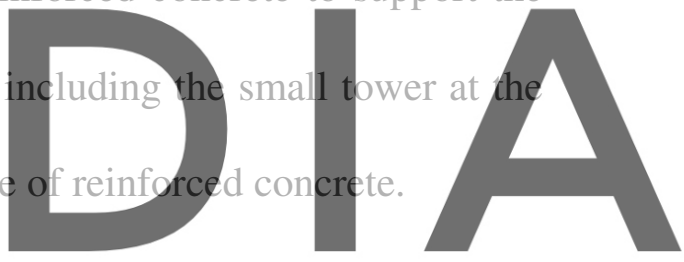

The explode view of the geometrical model and the main components are shown in Fig.3.

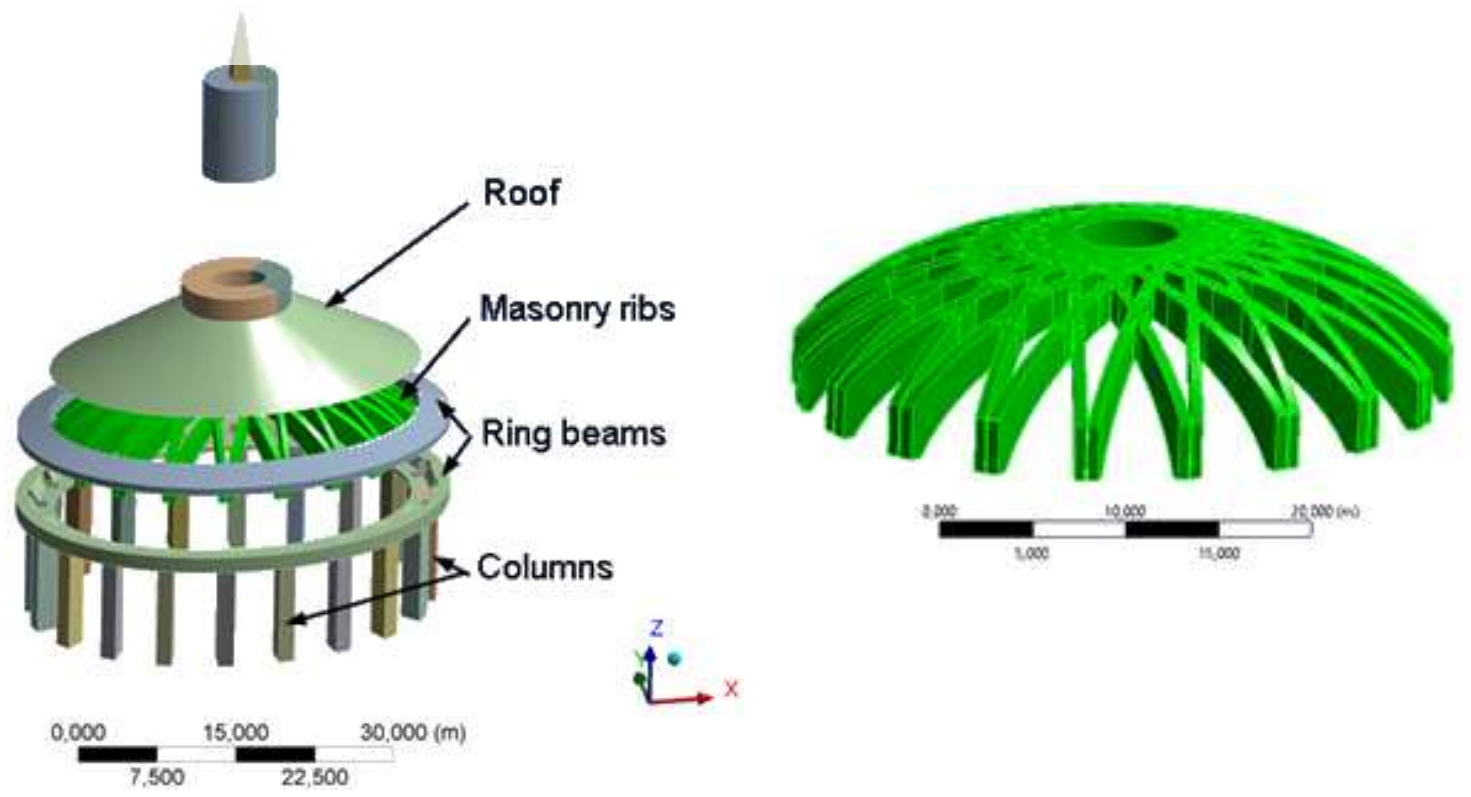


Figure 3. Geometrical model of the Church of the Laboral main parts: explode view (left) and masonry ribs (right)

\subsection{Finite element model}

Numerical model uses several finite elements to simulate the structural behaviour of the dome. The concrete and masonry components were modelled using the element SOLID65 and SOLID185 from ANSYS®. Both are an eight-node solid element, with three degrees of freedom at each node (translations in nodal $\mathrm{x}, \mathrm{y}$, and $\mathrm{z}$ directions). They are suitable numerical elements to simulate masonry and concrete components. SOLID65 supports plastic deformation, cracking in three orthogonal directions, and crushing. SOLID185 supports plasticity, stress stiffening, large deflection and large strain [8-10].

Furthermore, elements type SOLID186 and SOLID187 were used to mesh the conical roof and the smallest parts of the Church. They are three-dimensional higher order solid elements that exhibits quadratic displacement behavior. SOLID186 is a twenty-node solid element with three degrees of freedom per node. SOLID187 is a ten-node solid element and tetrahedral in shape [8-12].

Contact between structural components, masonry ribs, conical roof, upper and the small tower at central skylight, lower rings and pillars, were simulated using pairs of contact elements, CONTA174 and TARGET170 [8-12].

The Multizone mesh method was used to solve the complex meshing of the structure. This method divides automatically the geometry in mapped regions and free regions. Then, it
generates a pure hexahedral mesh where possible and fills the more aifficult regions with
unstructured mesh. This meshing method is sultable to mesh complex geometries.
The mesh sizing parameter ranges between $0.1 \mathrm{~m}$ for the masonry ribs and $0.2 \mathrm{~m}$ for the ring
beams. The finite element model has more than 1,500,000 nodes and 1,200,000 elements (see
Fig.4).

Register for free at https//www.scipedia.com to download the version without the watermark
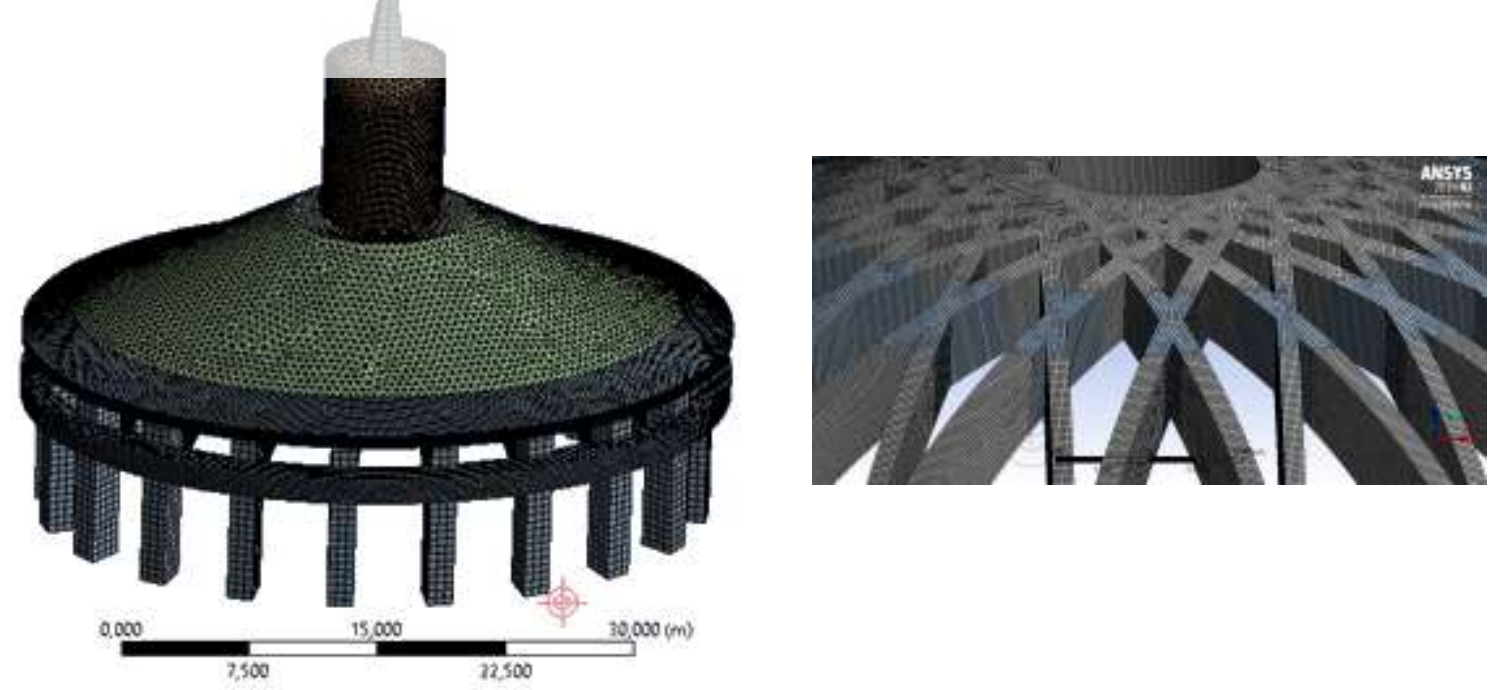

Figure 4. Mesh of the church in the Universidad Laboral: overall view (left) and masonry ribs detail (right) 


\subsection{Material properties}

The structural behavior of the masonry dome was analyzed using a macro-modelling strategy, based on previous research works [4-6]. In this sense, mortar and unit-mortar interface are smeared out in the complex geometrical model of the roof, due to a necessary compromise between accuracy and efficiency in this specific case.

Nonlinear material models were used to simulate masonry and concrete material behavior. Two material models were combined to study both material failure modes, cracking and crushing: Drucker-Praguer material model for compression stresses, and Willam-Warnke material model for tension stresses, in order to predict both material failure modes: cracking and crushing [13-14].

In order to obtain the main masonry properties, other minor structure located near the building was tested. The brick is $0.24 \mathrm{~m}$ long, $0.11 \mathrm{~m}$ wide and $0.06 \mathrm{~m}$ thick. The mortar thickness is $0.01 \mathrm{~m}$ in all directions. [14-15].

\section{The main material properties considered in the FEM model are shown in Table 1.}

\section{Table 1: Material properties}

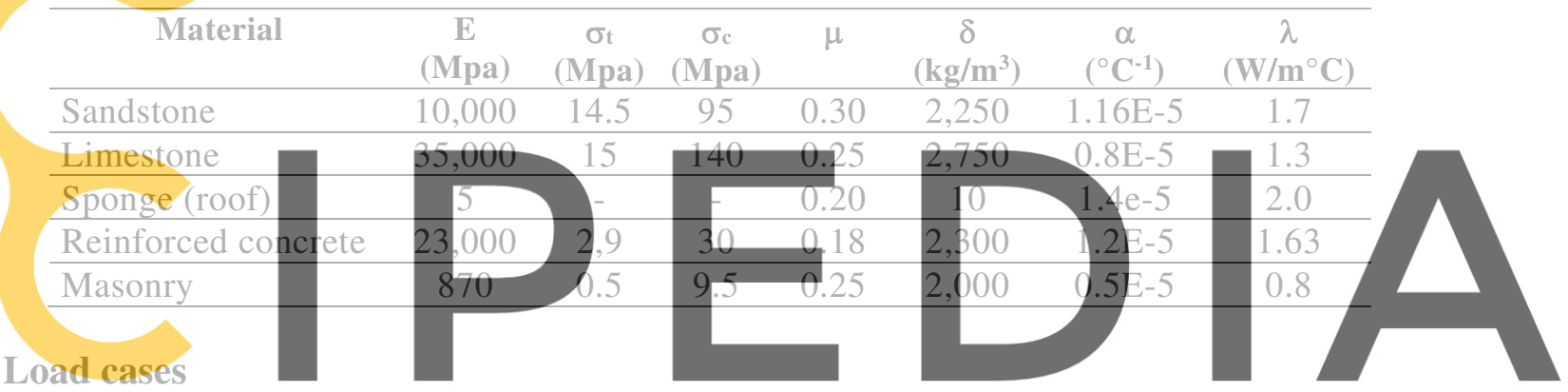

3.4 Load cases

In this work, a thermal analysis was carried out to determine the temperature distribution in

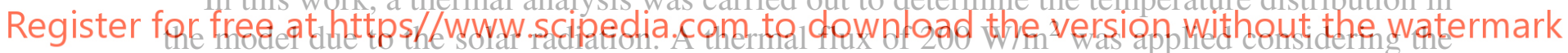
worst climatic condition in the summer [16]. Convection film coefficients were obtained from the Standard UNE-EN ISO 6946, as it is shown in Tabie 2 beiow, ranging from 25 to 5.88 $\mathrm{W} / \mathrm{m}^{2} \mathrm{~K}[17-18]$.

Table 2: Convection film coefficients

\begin{tabular}{lccc}
\hline Film coefficient & \multicolumn{3}{c}{ Thermal flux direction } \\
\hline & Upper & Horizontal & Lower \\
\hline Inner surfaces & 10.0 & 7.7 & 5.88 \\
\hline Outer surfaces & 25.0 & 25.0 & 25.0 \\
\hline
\end{tabular}

Furthermore, a coupled thermal-structural analysis was carried out considering the temperature distribution obtained in the previous thermal analysis.

Dead load and snow load were considered, taking into account the following parameters:

- Dead load: density of the main materials, including a specific study to the conical roof.

- Snow load: a constant pressure of $450 \mathrm{~Pa}$ were applied in the exterior surface of the roof [16]. 
To solve the couple thermal-structural analysis the temperature distribution previously obtained was applied to nodes and transferred to the model. The nonlinear problem was solved using a Newton-Raphson method with adaptive descent including plastic material properties. The maximum number of equilibrium iterations was 100 , with an initial step of 0.01 over 1 . As convergence control, the displacement was considered with a minimum tolerance of 0.01 [1012].

The coupled thermal-structural problem was solved in a four Intel ${ }^{\circledR}$ Xeon ${ }^{\circledR}$ Gold 6230 CPU @ 2.1 GHz machine, with 256 GB memory and 4 TB Raid0 NvMe SSD disks, distributed among 80 cores. Total CPU time was about 10,000 seconds, with 14 load steps and 300 iterations.

\section{NUMERICAL RESULTS AND DISCUSSION}

\section{Main results}

In this section, the main numerical results from the thermal and structural analyses are presented. Results include a detailed cracking and crushing analyses.

Figure 5 shows the temperature distribution obtained in the thermal analysis where summer climatic conditions were applied. Temperature values ranges between $16{ }^{\circ} \mathrm{C}$ and $21.6{ }^{\circ} \mathrm{C}$ at the upper part of the masonry ribs. These variations could cause thermal stresses in the dome
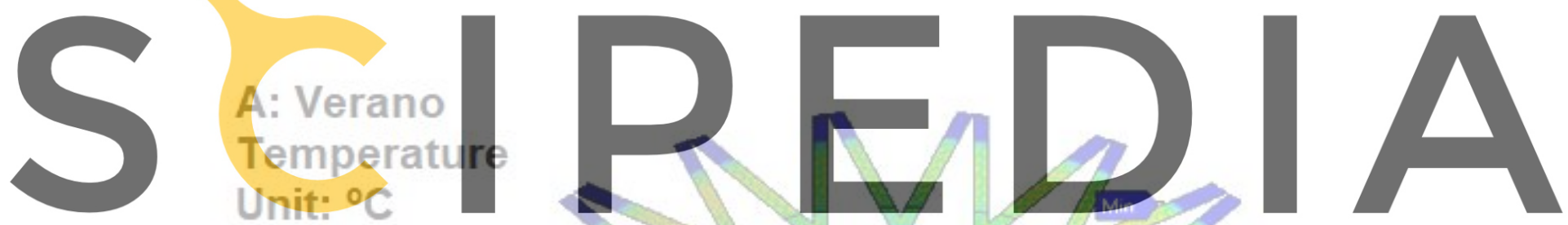

Register for free 21 thttps //www.scipedia.com to download the version without the watermark
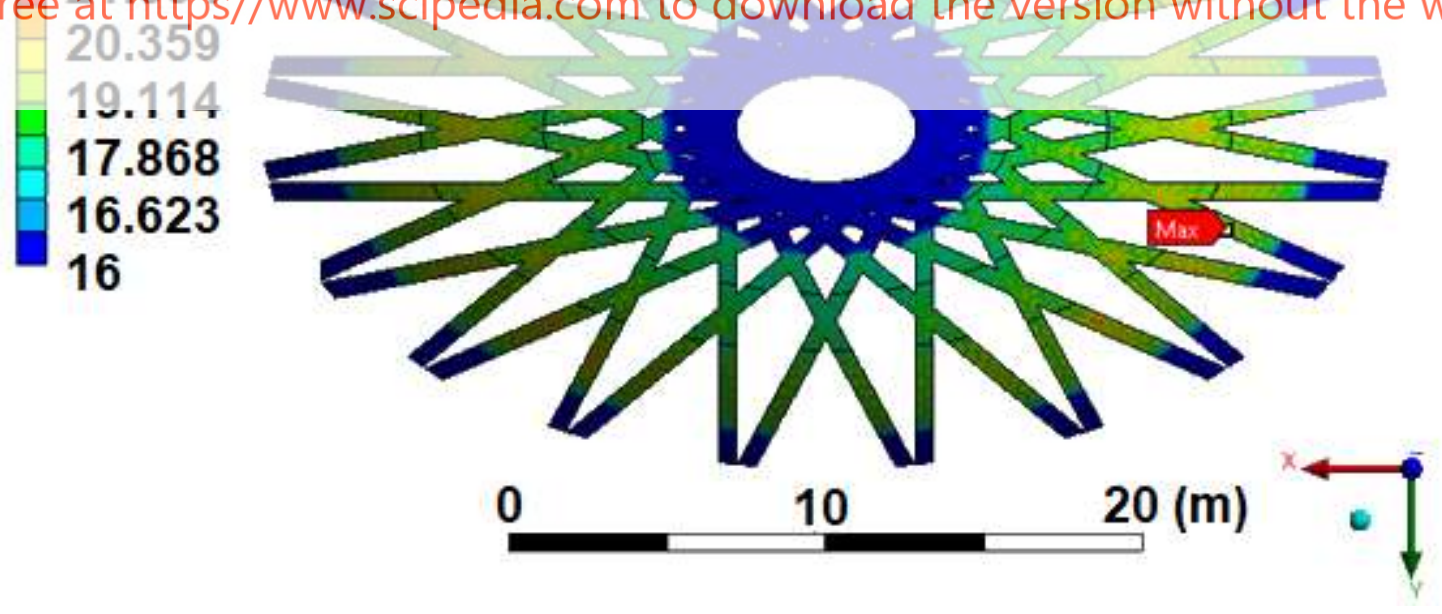


\section{A: Verano}

Temperature Unit: ${ }^{\circ} \mathrm{C}$

21.604

20.359

19.114

17.868

16.623

16

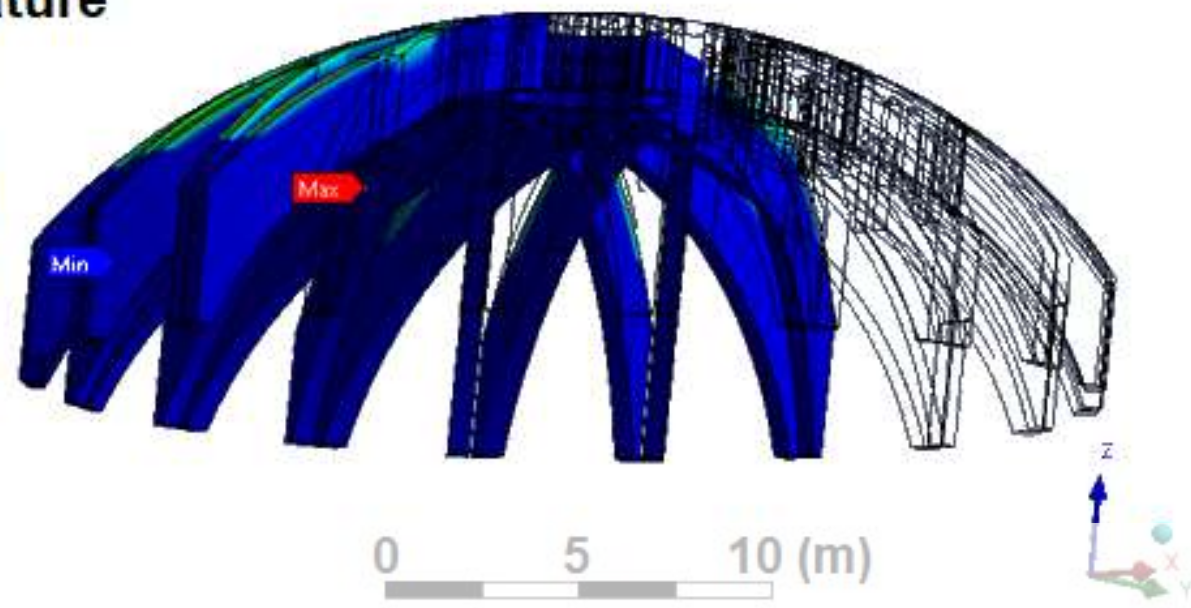

Figure 5. Temperature distribution in masonry ribs: zenithal view (upper) and isometric view detail (lower)

Figure 6 shows the main results of the coupled thermal-structural nonlinear analysis. Figure 6 upper shows the maximum displacements of the dome and Figure 6 lower, the crack patterns

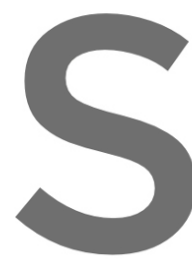
obtained when the total load is applied on the dome.
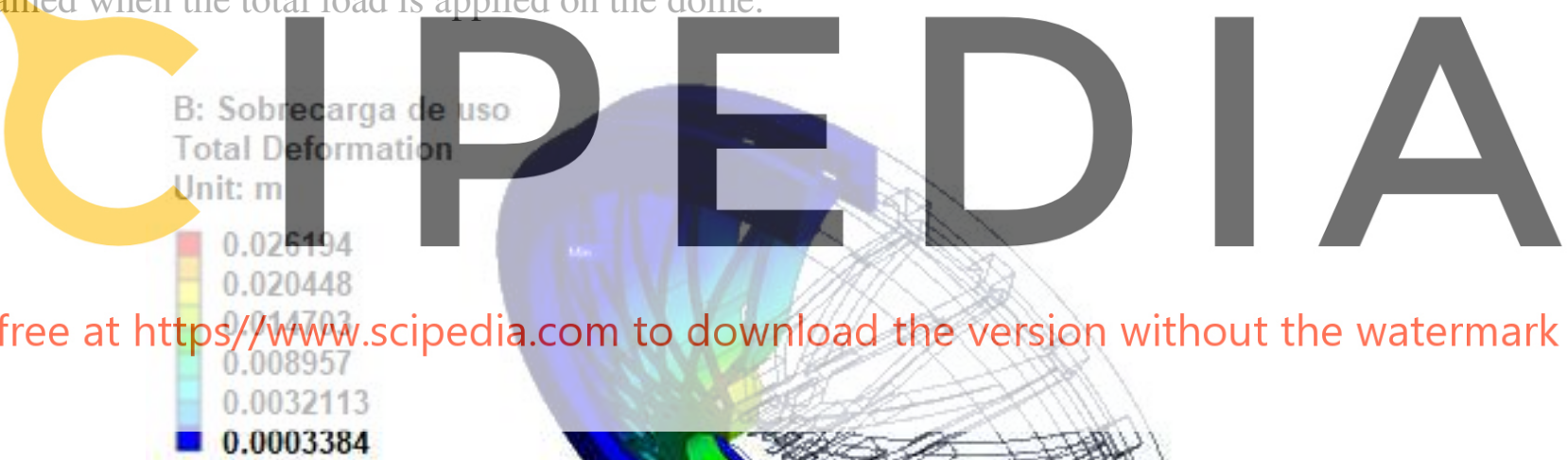

Register for free at https $/ W_{W W} W^{3}$.scipedia.com to download the version without the watermark

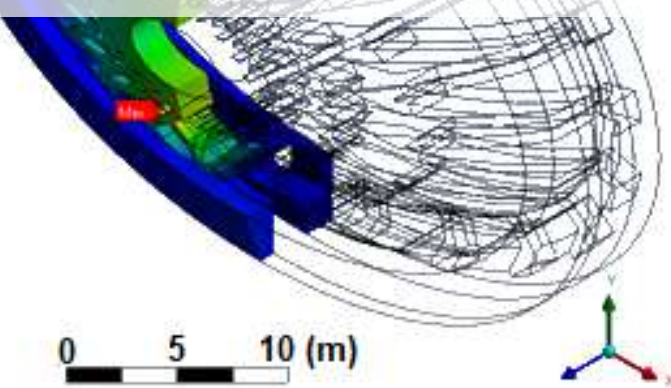




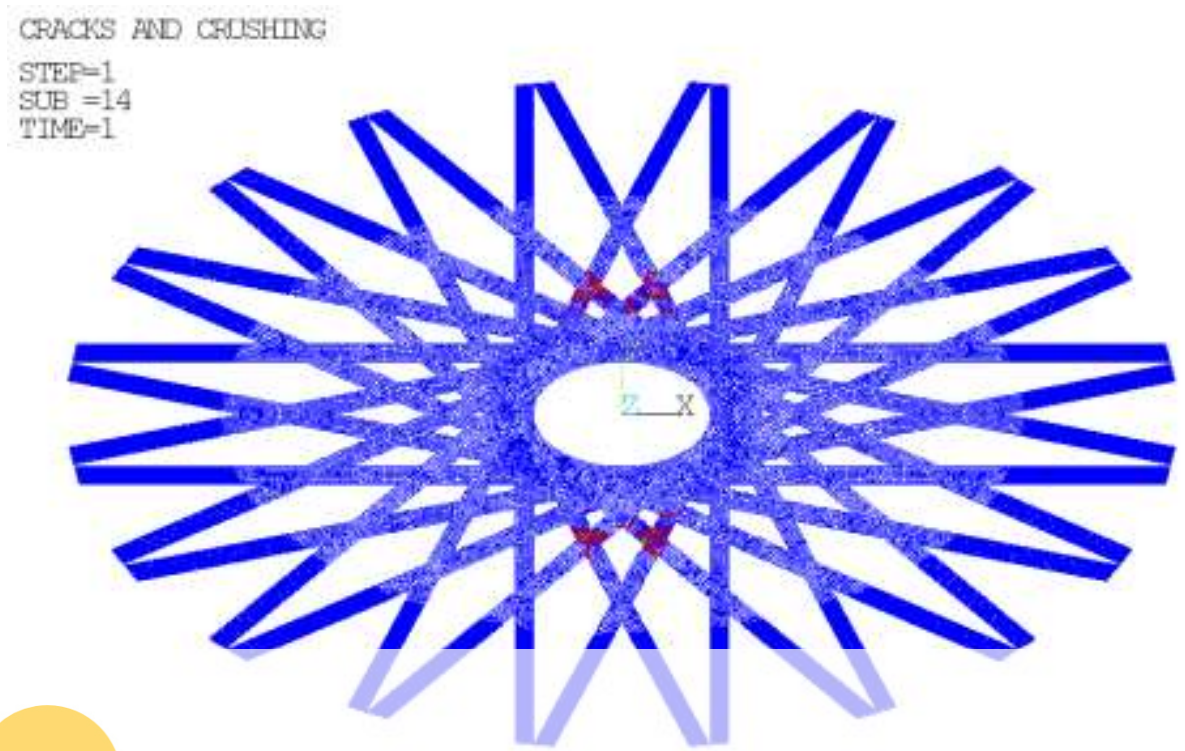

Figure 6. Maximum masonry ribs displacement (upper) and crack pattern (lower)

Maximum displacement value is about $0.026 \mathrm{~m}$, which lead a ratio of 962 between short dome length and vertical displacement. With respect to the crack patterns, short masonry ribs present crushing under compression stresses in the upper zones, and cracking failures at the lower part of the short ribs.

In the non-linear region of the respense, subsequent dracking occurs a more load is applie to the dome. Cracks grow in the constant region, located at the short ribs, and the masonry ribs starts cracking out towards the supports at a $20 \%$ of the maximum load (see Figure 6). Figure 6 shows the details of the crack evolution at 6 different points of the analysis $(0.2 \mathrm{~s}, 0.325 \mathrm{~s}$,

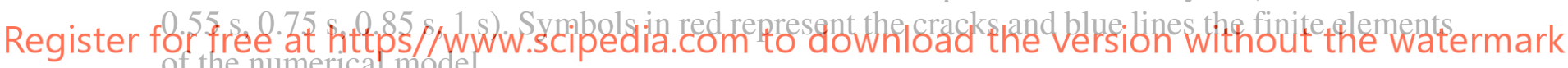
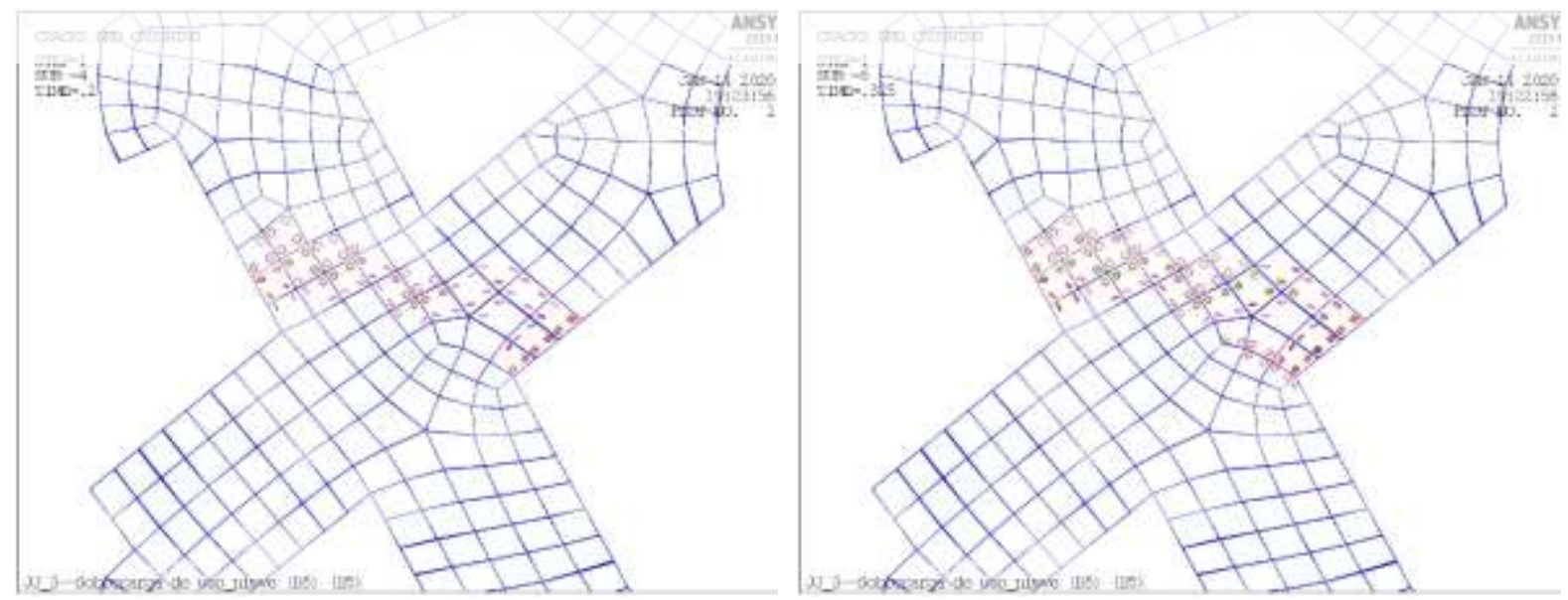

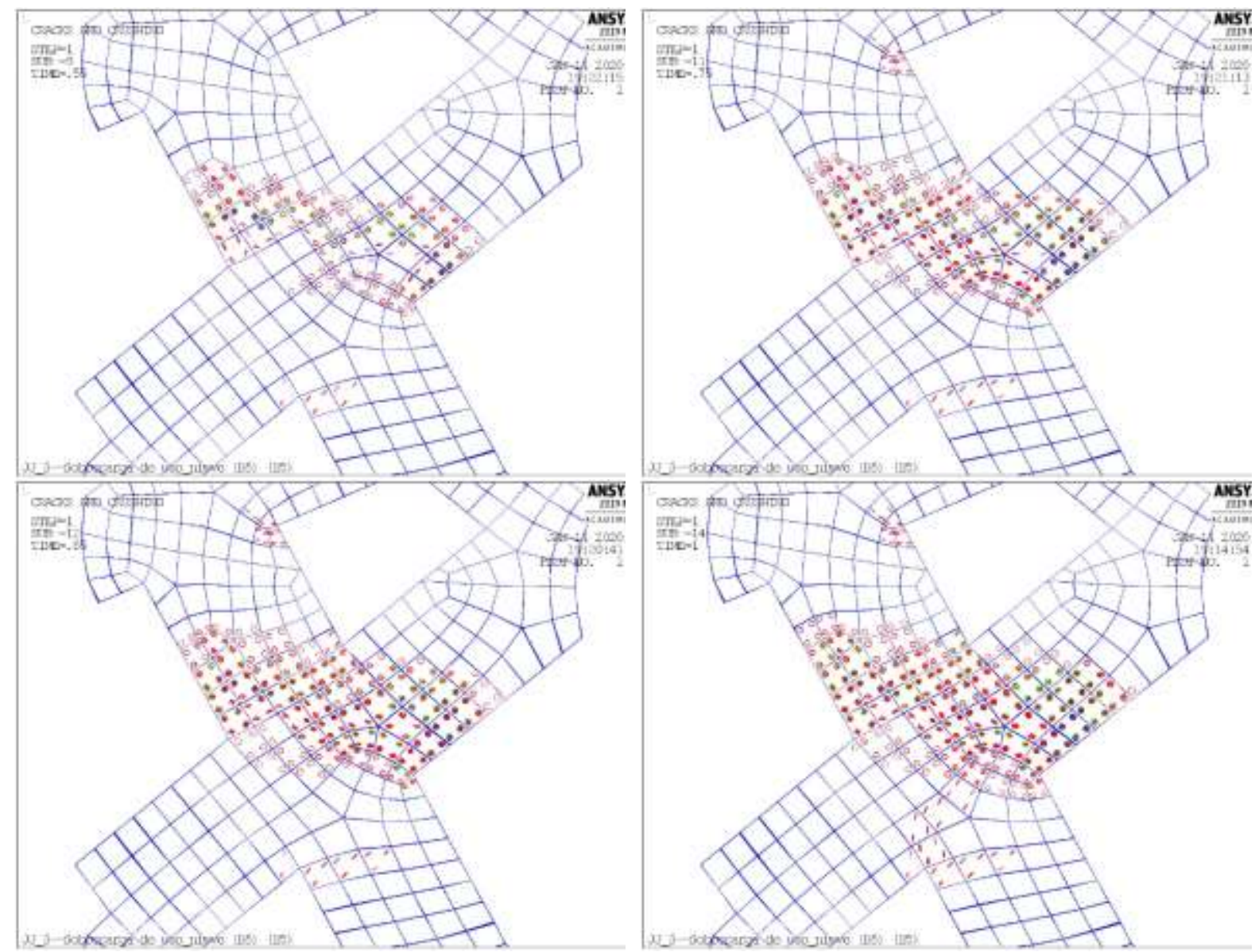

Figure 7. Crack patterns in the central part of the masonry ribs at different load steps

\section{CONCLUSIONS}

This paper has proved that the use of advanced numerical methods helps to obtain the structural response of a complex nonlinear model, such as the case studied in this work. The most important findings are the following:

- To define the complex geometry of the Church in the Universidad Laboral it is necessary to use a three-dimensional parametric design program.

- In order to obtain a regular tetrahedral mesh, it is necessary to use a MultiZone mesh method. In this study, suitable element size ranges between 0.1 and 0.2.

- The thermal gradient in the masonry ribs causes significantly less stresses and deformation than the expected. The low stress levels are due to the conductivity properties of the material and the air chamber in the interior of the Church.

- The use of nonlinear numerical models including contacts are suitable to study the thermal and structural behavior of complex geometries and assembles of different structural elements, such as ribs, columns and annular rings. 
- A constitutive material model to simulate concrete and masonry models is very efficient to simulate the behavior of bricks. In this case, William-Warnke and Drucker-Prager models were combined to obtained accurate results.

- The numerical results of the coupled thermal-structural model show cracking patterns in the short masonry ribs. These cracks caused some deterioration in the elliptical dome.

In this work, our experience in numerical simulation provided an important contribution to know the structural conditions of an important cultural heritage. The structural behavior of the elliptical dome of the Church in the Universidad Laboral was analyzed using advanced numerical models and the most critical points were located. This study is very important to prevent and assist the conservation, or retrofitting of this building.

Acknowledgements. The authors greatly appreciate the collaboration of the GICONSIME Research Group at the University of Oviedo, and also to Ignacio Rojo Blanco, a Master industrial engineering student at the University of Oviedo. We would also like to thank Swanson Analysis Inc. for the use of the ANSYS University program and Workbench simulation environment. Furthermore, authors must acknowledge the financial support provided by regional funds from the Gobierno del Principado de Asturias and FICYT through the Research Project GRUPIN-IDI/2018/000221 also co-financed with FEDER funds. Finally, authors must acknowledge the alumni association of La Laboral and, particularly, to Victor Camblor Prieto to provide real photographs and some useful information to prepare this research work.

\section{REFERENCES}

[1] A.M. Rodríguez, J.J. del Coz-Diaz, et.al., Los talleres de la Universidad Laboral de Gijón $2^{\text {th }}$ Edition, Ed. Cicees, 2007.

[2] Gianni Bartoli, Michele Betti,Claudio Borri. Numerical Modeling of the Structural Behavior of Brunelleschi's Dome of Santa Maria del Fiore. International Journal of Architectural Heritage 2014; 9(4): 408-429.

[3] J.J. del Coz-Diaz, A. Lozano Martinez-Luengas, J.M. Adam, A. Martin Rodriguez., Nonlinear hygrothermal failure analysis of an external clay brick wall by FEM-A case study. Construction and Building Materials 25 (2011) 4454-4464.

[4] J.J. del Coz-Diaz, P.J. Garcia Nieto, F.P. Alvarez Rabanal, A. Lozano Martinez-Luengas. Design and shape optimization of a new type of hollow concrete masonry block using the finite element method. Engineering Structures 33 (2011) 1-9.

[5] P.B. Lourenco. Computational strategies for Masonry Structures. Ph. Thesis. Delft University Press. ISBN 90-407-1221-2, (1996)

[6] Saloustros, S., Pelà, L., Cervera, M. and Roca, P. Tracking of Localized Cracks in the Finite Element Analysis of Masonry Walls. In: R. Aguilar et al. (Eds.): Structural Analysis of Historical Constructions, RILEM Bookseries 18 (2019), pp. 919-928.

[7] Wikipedia. $\quad$ https://en.wikipedia.org/wiki/Universidad_Laboral_de_Gij\%C3\%B3n. Accesed January $15^{\text {th }}, 2020$. 
[8] Moaveni S. Finite element analysis. Theory and application with ANSYS. New York: Prentice Hall; 2007.

[9] Madenci E, Guven I. The finite element method and applications in engineering using ANSYS. Berlin: Springer-Verlag; 2007.

[10] ANSYS® Academic Research Mechanical, Release 19.2, Help System, Analysis Guide, ANSYS, Inc.

[11] Zienkiewicz, O.C. and Taylor, R.L. The finite element method. McGraw Hill, Vol. I., (1989), Vol. II, (1991).

[12] Idelsohn, S.R. and Oñate, E. Finite element and finite volumes. Two good friends. Int. J. Num. Meth. Engng (1994) 37:3323-3341.

[13] Fuschi P, Dutko M, Peric D, Owen DRJ. On numerical integration of the five parameter model for concrete. Computer \& Structures 1994; 53(4):825-38.

[14] Willam KJ, Warnke ED. Constitutive model for the triaxial behaviour of concrete. Proceedings of the international association for bridge and structural engineering, vol. 19. Bergamo (Italy): ISMES; 1975. p. 174-8.

[15] Calderini C, Cattari S, Lagomarsino S. The use of the diagonal compression test to identify the shear mechanical parameters of masonry. Constr Build Mater 2010;24(5):677-85.

[16] CTE Spanish rule - DB-SE-AE: Structural Security, Ministry of Buildings, March 2006.

[17] UNE-EN-1745, Masonry and Masonry Products. Methods for Determining Design Thermal Values, AENOR, Madrid, 2002.

[18] UNE-EN ISO 6946, Elements and Construction Components. Resistance and Thermal Transmittance: Calculation Method, AENOR, Madrid, 1997. 